\title{
A Study on the Optimization of High School Buildings for Evacuation Safety: Classroom Layout and Ramps in Korea
}

\author{
Chang-Jun Choi ${ }^{1}$,Ha-Sung Kong ${ }^{* 2}$ \\ ${ }_{1 * 2}$ Fire and Disaster Prevention, Woosuk University Graduate Sch., WANJU, Korea \\ bearjun1@ daum.net ${ }^{1}, \underline{119 w s u @ \text { naver.com }^{2}}$
}

Article History: Received: 11 January 2021; Accepted: 27 February 2021; Published online: 5 April 2021

\begin{abstract}
This study used the Pathfinder program to evaluate evacuation safety by assuming evacuation training in high school buildings and changing classroom layout. Analysis of the final evacuation requirements for Scenario 2, which currently has a concentration of classrooms on the third floor of the building, showed that Scenario 2 reduced 29.6 seconds to 173.9 seconds compared to Scenario 1's 203.5 seconds. However, the analysis of Scenario 3, in which 10 classrooms and personnel of three grades were placed equally on the left and right sides of the building, showed that the final evacuation requirements were reduced 3.9 seconds to 170.0 seconds compared to Scenario 2, but there was no significant difference. Scenario 3, which has more the efficiency of school year operation by placing classroom layout on the same floor by grade level than Scenario 2 , in which more classrooms and students were placed downstairs. In each scenario, an analysis of the final evacuation requirements showed that the evacuation exit $\mathrm{T} 1$ on the left side of the building was 28 seconds or more shorter than T3 on the right side of the building. Therefore, it was analyzed that proper classroom layout and ramp facilities in high school buildings ensure evacuation safety
\end{abstract}

Keywords: Evacuation safety, Pathfinder, Classroom layout, Ramp, Stair.

\section{Introduction}

Most of the existing school buildings are aged. Therefore, the durability and stability of existing school buildings are slowly deteriorating along with electrical equipment, increasing the risk of fire.

According to data by subject (from 2015 to 2019), there have been a total of 956 fires in schools, including special schools, vocational training centers, and universities, 179 fires in 2015, 203 fires in 2016, 197 fires in 2017, 205 fires in 2018, and 172 fires in 2019. Among them, fires at high school sites accounted for a total of 173 cases, 40 cases in 2015, 35 cases in 2016, 30 cases in 2017, 38 cases in 2018, and 30 cases in 2019[1].

Property damage in the event of a sudden fire in an aging school building with a high risk of fire is also a serious problem, but the loss of life for teenagers is a serious problem. Therefore, it is important to evacuate quickly when an actual fire breaks out. In particular, the proper placement of students in classrooms, the main space of students in school buildings, is an important factor because the time it takes for students to evacuate to a safe place is one of the factors directly related to their lives.

Choi Seo-yeon and Lee Ha-yeon (2016) have been recognized as an essential and important factor in the prevention and management of accidents throughout society since the 2014 Ferry Sewol disaster, especially schools are preparing measures to prevent and manage accidents such as building a safety infrastructure foundation, educating students, and managing school safety[2].

Lee Jung-soo and Kwon Heung-soon (2011) found that in the case of middle and high school facilities in Korea, women and middle schools are more disadvantageous than men and high schools in terms of evacuation behavior. It also said that the standard for body dimensions and evacuation speed that affect evacuation simulations is significantly different from the existing application figures[3].

Im Won-haeng (2005) said that while the school building was composed of a large and open space, the spread of fire was limited due to the partitioning of combustibles, and a wide evacuation route suitable for two-way evacuation was secured, making it suitable for evacuation[4].

Hong Seong-guk (2017) said that although the school's combustion expansion prevention facilities are better than other facilities, they not only help expand flames and smoke gases in the event of a fire, but also interfere with students' evacuation activities and cause suffocation and burns. In theory, rather than selecting a refuge route, it is necessary to visit the site where the actual fire broke out, see if there are any problems or obstacles to escape, and to reduce the evacuation time by dispersing the areas where students are expected to experience bottlenecks during evacuation[5,13].

In the preceding study, the main studies included fire safety education in front-line schools, the difference between male and female evacuation time for middle and high school students, obstacles to evacuation fire facilities, and ways to resolve bottlenecks, so it is not enough to evaluate and improve evacuation safety. In this study, we would like to come up with a plan to optimize classroom layout as there is a lack of research that the proper classroom arrangement on each floor can shorten the evacuation requirements under the circumstances of evacuation drills, assuming disasters such as fires or earthquakes in high school classrooms.

Through evacuation simulation for high school buildings, the study aims to analyze the RSET: Required Safe Egress Time for all inmates according to the classroom layout of the school building by reflecting the time of 
evacuation and various scenarios along the evacuation route in the situation of students' evacuation training as variables. Pathfinder is used as an evacuation simulation software. The study seeks to suggest ways to optimize classroom layout for evacuation safety.

\section{Evacuation Simulation}

2.1 Structure of the target building

The target building is $\mathrm{OO}$ high school building and $\mathrm{OOO}$ is also located in $\mathrm{OO}$ city. It is a 10 class-sized school in one grade with a total of 30 classrooms, 4 science rooms, and 2 creative convergence rooms on the first, second and third floors, and on the fourth floor, there are special rooms such as auditoriums, health rooms, math rooms, and computer rooms. The building is 126.9 meters wide and 28.2 meters long and has a floor height of 4 meters. The width of the central exit is $9 \mathrm{~m}$ and the width of both exits is $4.8 \mathrm{~m}$, and the width of the corridor on each floor is $2.4 \mathrm{~m}$, which satisfies the rules on the standards for evacuation and fire prevention of buildings specified by the Building Act, and the installation criteria of Article 151 st steps (the corridor is at least $1.2 \mathrm{~m}$, and two or more direct statistics (or ramps) that lead to the floor (or ramps) of $0.9 \mathrm{~m}$ )[6].

The design drawings of the school building are shown in Figure 1.

Table 1. Width and installation criteria of the corridor

\begin{tabular}{|c|c|c|r|r|}
\hline Sortation & $\begin{array}{c}\text { A corridor } \\
\text { with living } \\
\text { rooms on } \\
\text { both sides }\end{array}$ & $\begin{array}{r}\text { Other } \\
\text { corri } \\
\text { dor }\end{array}$ & $\begin{array}{r}\text { Targe } \\
\text { t building }\end{array}$ & $\begin{array}{r}\text { Jud } \\
\text { gment }\end{array}$ \\
\hline $\begin{array}{c}\text { High } \\
\text { school }\end{array}$ & $2.4 \mathrm{~m}$ or more & $\begin{array}{c}\text { over } \\
1.8 \mathrm{~m}\end{array}$ & $2.4 \mathrm{~m}$ & fit \\
\hline
\end{tabular}

Source: Rules on the Standards for Evacuation, Fire Protection, etc. of Buildings, Article 15-2 (Width and Installation Standards of corridors)

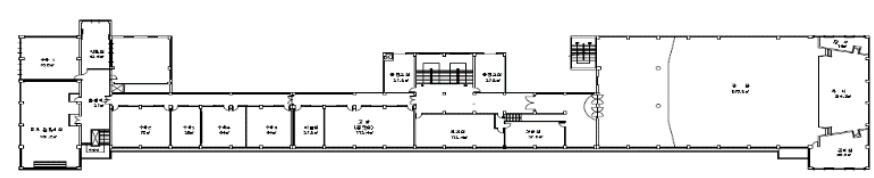

(d)

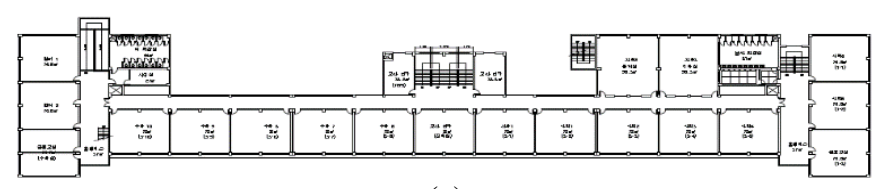

(c)

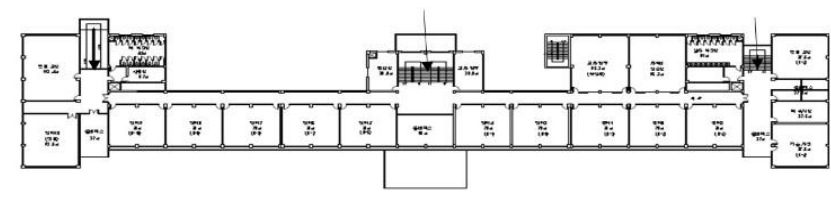

(b)

T4

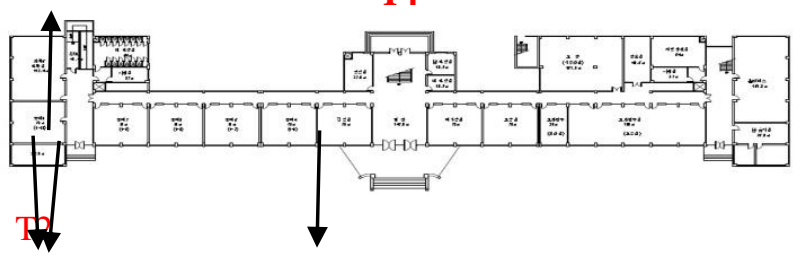

(a)

Figure 1. Structural plan of the main building of OO High School on the $4^{\text {th }}$ floor

(a) Floor plan of the $1^{\text {st }}$ floor, (b) Floor plan of the $2^{\text {nd }}$ floor, (c) Floor plan of the $3^{\text {rd }}$ floor, (d) Floor plan of the $4^{\text {th }}$ floor

The facility used in this study is an elderly care hospital located in OOO city in the OOO region that has a The "density of occupants by type of use according to the purpose of the building subject to the installation of the 
evacuation safety zone" was applied to the number of people assigned to the classroom.

The floor area of the classroom is $72 \mathrm{~m}^{2}$, and the class with the largest number of students is $30\left(2.4 \mathrm{~m}^{2} / 1\right)$, and the class with the smallest number is $25\left(2.9 \mathrm{~m}^{2} / 1\right)$, so the number of students in the classroom satisfies the calculation criteria.

2.2 Classroom capacity

The "density of occupants by type of use according to the purpose of the building subject to the installation of the evacuation safety zone" was applied to the number of people assigned to the classroom[7].

The floor area of the classroom is $72 \mathrm{~m} 2$, and the class with the largest number of students is $30(2.4 \mathrm{~m} 2 / 1)$, and the class with the smallest number is $25(2.9 \mathrm{~m} 2 / 1)$, so the number of students in the classroom satisfies the calculationcriteria.

Table 2. Calculation criteria and determination of capacity

\begin{tabular}{|c|c|c|c|c|}
\hline ity Usabil & $\begin{array}{l}\text { Standa } \\
\text { rd for } \\
\text { calculating } \\
\text { the } \\
\text { number of } \\
\text { classroom } \\
\text { capacity }\end{array}$ & $\begin{array}{l}\text { Numbe } \\
\mathbf{r} \text { of } \\
\text { Acceptance } \\
\text { Criteria } \\
\text { Students }\end{array}$ & $\begin{array}{c}\begin{array}{c}\text { Targ } \\
\text { et } \\
\text { Building } \\
\text { actu }\end{array} \\
\text { al } \\
\text { number } \\
\text { of } \\
\text { students }\end{array}$ & $\begin{array}{l}\text { Judg } \\
\text { ment }\end{array}$ \\
\hline \multirow{2}{*}{$\begin{array}{l}\text { Classr } \\
\text { oom }\end{array}$} & \multirow{2}{*}{$\begin{array}{c}1.9 \mathrm{~m}^{2} \\
\text { /person }\end{array}$} & \multirow{2}{*}{$\begin{array}{c}72 \mathrm{~m}^{2} \\
/ 1.9 \mathrm{~m}^{2} \\
/ \text { person } \\
= \\
\text { 38people }\end{array}$} & $\begin{array}{c}25 \mathrm{pe} \\
\text { ople } \\
(2.9 \\
\mathrm{m}^{2} \\
\text { /person) }\end{array}$ & \multirow{2}{*}{ fit } \\
\hline & & & $\begin{array}{c}\text { 30pe } \\
\text { ople } \\
(2.4 \\
\mathrm{m}^{2} \\
\text { /person) }\end{array}$ & \\
\hline
\end{tabular}

\subsection{Composition of Scenario}

The scenarios were set up in three different ways as shown in Table 3, where students took refuge using T1 on the slope to the left of the school building, T2 on the playground of the building's central entrance, and T3 on the stairway to the right of the building, and T4 on the back of the central entrance. In Scenario 1, the current classroom layout was set. Scenario 2 hypothesized that the lower the number of students on the lower floor, the shorter the time required for evacuation, leaving four classrooms on the third floor, two classrooms on the left and right, and the rest on the lower floor and setting up similar student numbers on the left and right sides. Scenario 3 sets the number of classrooms and the number of students on each floor to be the same for the efficiency of school year management. The criteria for total evacuation requirements were the time when all students finally passed the first floor ramps, stairs and four central front exits. The elevator was removed from the evacuation route by not using it.

Table 3. Configuration of Scenarios

\begin{tabular}{|c|c|c|c|c|c|}
\hline \multirow[b]{2}{*}{$\begin{array}{l}\text { Clas } \\
\text { sroom } \\
\text { layout } \\
\text { Scen } \\
\text { ario }\end{array}$} & \multicolumn{4}{|c|}{$\begin{array}{l}\text { Scenario conditions(class layout by } \\
\text { floor (number of students; people)) }\end{array}$} & \multirow[b]{2}{*}{$\begin{array}{l}\quad E \\
\text { vacua } \\
\text { tion } \\
\text { exit } \\
\quad \text { se } \\
\text { t up }\end{array}$} \\
\hline & $\begin{array}{r}\mathbf{F} \\
\text { loor }\end{array}$ & \begin{tabular}{l}
\multicolumn{2}{c}{ The } \\
left side \\
of a \\
building \\
Num \\
ber of \\
classes \\
(stud \\
ents)
\end{tabular} & $\begin{array}{c}\text { The } \\
\text { right } \\
\text { side of a } \\
\text { building } \\
\text { Num } \\
\text { ber of } \\
\text { classes } \\
\text { (students } \\
\text { ) }\end{array}$ & $\begin{array}{l}\text { Tot } \\
\text { al }\end{array}$ & \\
\hline $\begin{array}{l}\text { Scen } \\
\text { ario } 1\end{array}$ & st 1 & $\begin{array}{l}5(150 \\
)\end{array}$ & - & $\begin{array}{l}5(1 \\
50)\end{array}$ & ${ }_{1}^{\mathrm{T}}$ \\
\hline
\end{tabular}



Ramps in Korea

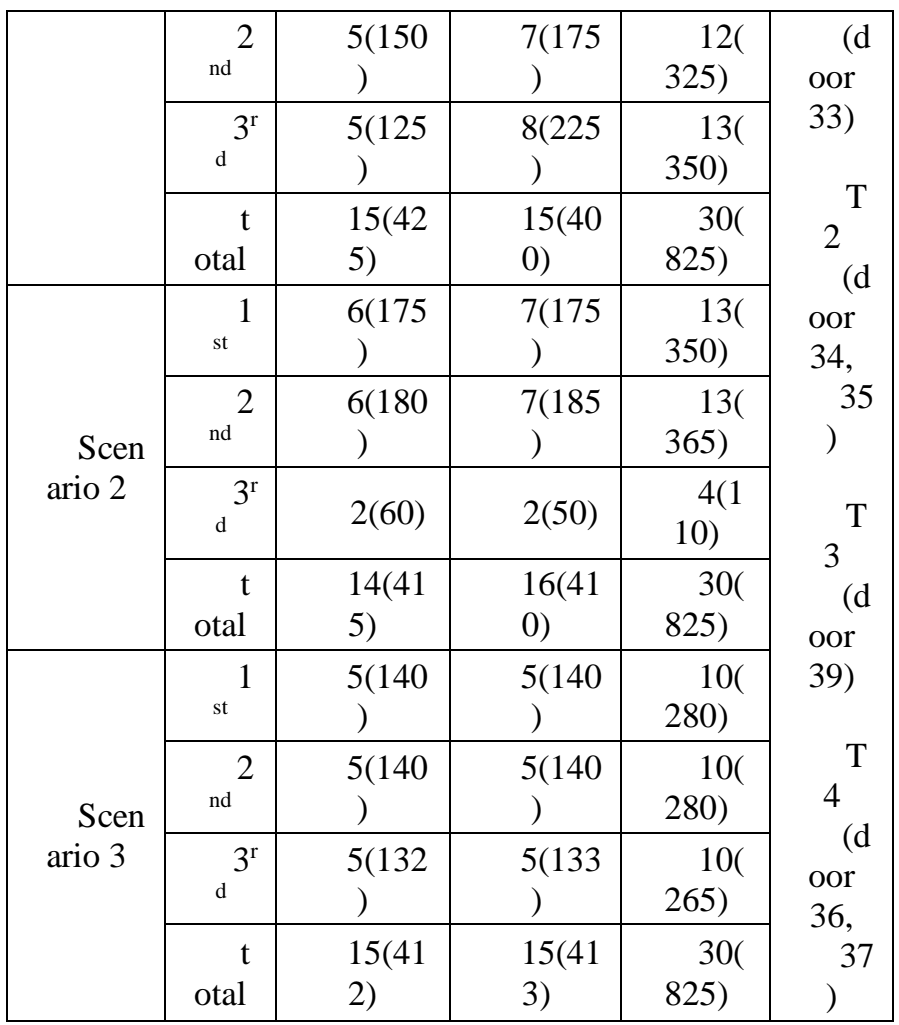

2.4 Deferred evacuation time and possible evacuation time

Evacuation delay time was used by the test formula "Estimation of evacuation start time" as shown in Expression (1)[8].

$$
\text { evacuation initiation time }(\min )=\sqrt{\sqrt{\sum A} / 30} \text {------ Expression (1) }
$$

The maximum compartment area of $\mathrm{A}=8.5$, since the floor area of the classroom is $72 \mathrm{~m} 2$. Therefore, evacuation initiation time $(\mathrm{min})=8.5 / 30=0.28$ minutes, which translates into 17 seconds.

However, since the evacuation training was notified in advance in this study, the detection time and recognition time of the fire detector should be considered in the event of a fire do not occur. Therefore, the evacuation start time was set at 30 seconds, including the time of evacuation after listening to the broadcast in 17 seconds of Form (1) because it was assumed that the person in charge was directly evacuated through the broadcast. The evacuation time is set at less than four minutes as shown in Table 4[9].

Table 4. Escape Time Criteria

\begin{tabular}{|c|c|}
\hline Building usage & $\begin{array}{c}\text { ASET } \\
\text { (available safe egress } \\
\text { time) }\end{array}$ \\
\hline $\begin{array}{c}\text { office, commercial and industrial buildings, schools, } \\
\text { universities(residents are familiar with the building's interior, alarms, } \\
\text { escape routes, and always awake) }\end{array}$ & 4 minutes, or less \\
\hline
\end{tabular}

2.5 Input variables and input values

In this study, the input variables reflected in the Pathfinder evacuation simulation[10] were divided into walking speed, evacuation initiation time, and shoulder width and applied as shown in Table 5. Among the input variables, the shoulder width reflects the body size of 20 Korean body measurements based on the standard body type by gender and age[11]. Therefore, the shoulder width was based on $39.8 \mathrm{~cm}$ for boys and $35.7 \mathrm{~cm}$ for girls. The walking speed was calculated by applying $1.19 \mathrm{~m} / \mathrm{s}$ to the average adult walking speed[12].

Table 5. Input variables and input values 


\begin{tabular}{|c|c|c|}
\hline $\begin{array}{c}\text { Input } \\
\text { variable }\end{array}$ & Input values & Evidence \\
\hline $\begin{array}{c}\text { walking } \\
\text { speed }\end{array}$ & $1.19 \mathrm{~m} / \mathrm{s}$ & $\begin{array}{c}\text { SFPE, "The SFPE Handbook of Fire } \\
\text { Protection Engineering", } 5^{\text {th }} \text { edition(2013), } \\
\text { Apply at adult average walking speed }\end{array}$ \\
\hline $\begin{array}{c}\text { evacuation } \\
\text { initiation time }\end{array}$ & 30 seconds & $\begin{array}{c}\text { Time for all occupants in the classroom } \\
\text { to recognize training and begin evacuation }\end{array}$ \\
\hline $\begin{array}{c}\text { shoulder } \\
\text { width }\end{array}$ & $\begin{array}{c}\text { adult man: } 39.8 \mathrm{~cm} \\
\text { adult woman: } \\
35.7 \mathrm{~cm}\end{array}$ & $\begin{array}{c}\ulcorner\text { Human Dimension Survey of } \\
\text { Koreans(2015)」Apply }\end{array}$ \\
\hline \multicolumn{2}{|c}{} \\
\hline \multicolumn{2}{|c|}{} \\
\hline
\end{tabular}

\section{Results and Considerations}

\subsection{Simulation Results}

In each scenario, the evacuation zone was set to $\mathrm{T} 1, \mathrm{~T} 2, \mathrm{~T} 3$ and $\mathrm{T} 4$, as shown in Figure 2, and the results were analyzed.

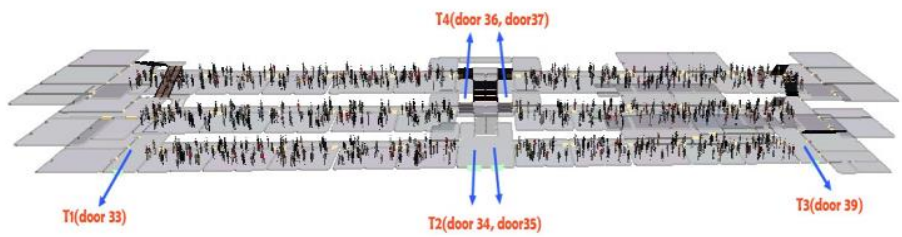

\subsubsection{Scenario 1}

Figure 2. Evacuation area of OO High School Building

Figure 3 4 shows the change in occupancy and flow of evacuation equipment according to scenario 1 until the evacuation is completed, starting evacuation 30 seconds after the evacuation drill is started using 4 evacuation zones, leaving the classroom layout of the current building intact.

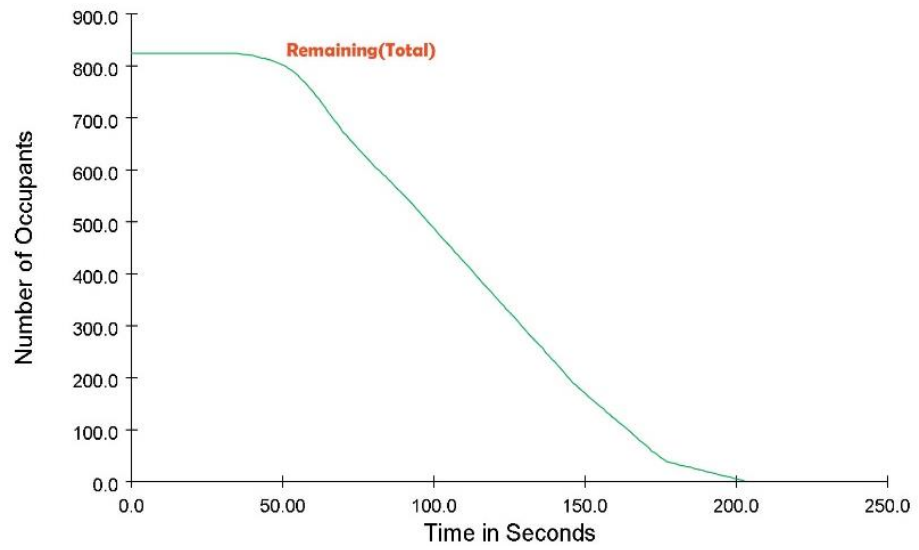

Figure 3. Changes in the number of occupants over time in Scenario 1

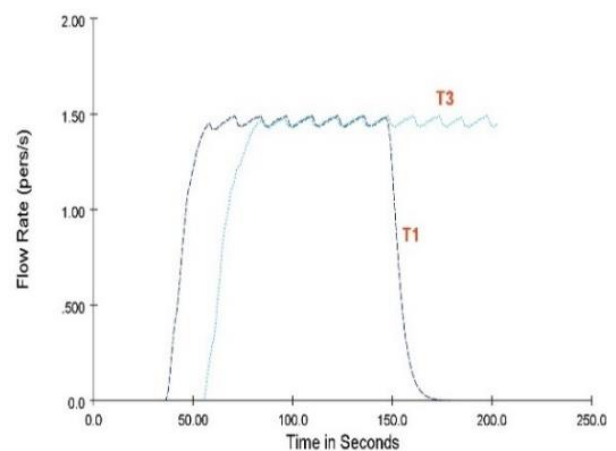

(a) 


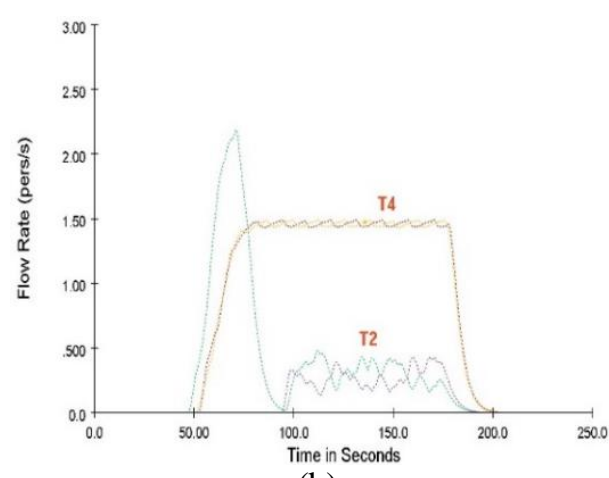

(b)

Figure 4. The Flow of Egress over Time in Scenario 1

(a) $\mathrm{T} 1, \mathrm{~T} 3$, (b) $\mathrm{T} 2, \mathrm{~T} 4$

\subsubsection{Scenario 2}

In Scenario 2, students' classrooms were arranged downstairs as much as possible, only four classes were placed on the third floor, and the number of students on the left and right sides were similarly set. Figures 5 6 show the changes in the number of people in the room and the flow of exits in accordance with Scenario 2 until evacuation began 30 seconds after the start of the evacuation drill and completed using ramps, stairs and central stairs on both sides of the building.

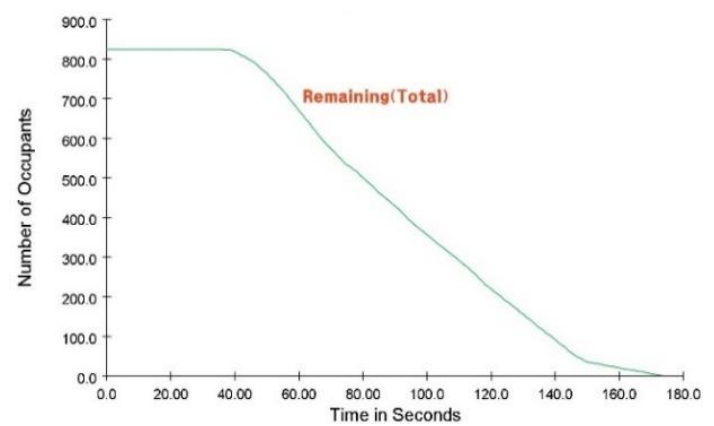

Figure 5. Changes in the number of occupants over time in Scenario 2

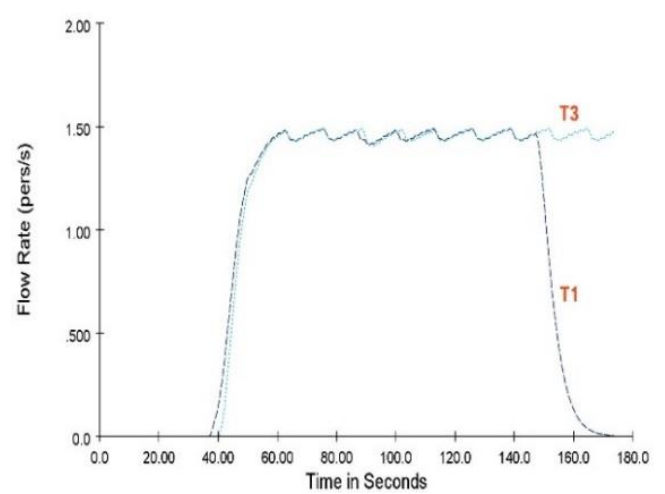

(a)

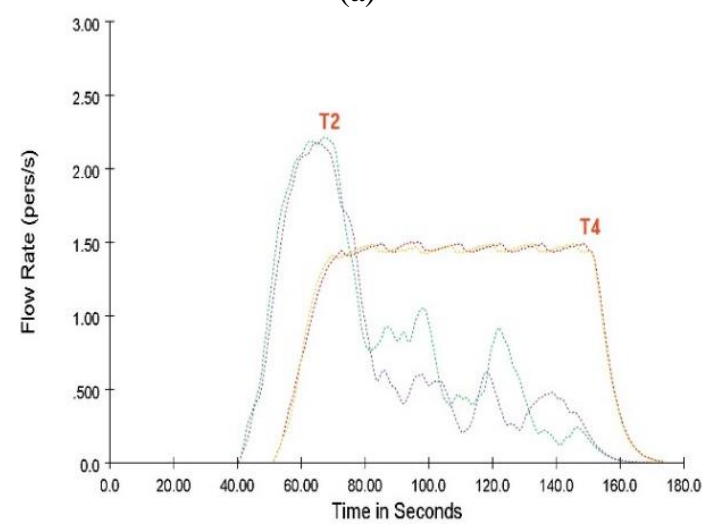


(b)

Figure 6. The Flow of Egress over Time in Scenario 2

\subsubsection{Scenario 3}

(a) T1, T3, (b) T2, T4

Scenario 3 places 10 classrooms in the same school year with similar numbers of students on the left and right sides of the building, with first graders on the first floor, second graders on the second floor and third graders on the third floor. Figures 7 8 show the change in the number of people in the room and the flow of refuge in accordance with Scenario 3 until the evacuation began 30 seconds after the start of the evacuation drill and completed using ramps, stairs and central stairs on both sides of the building.

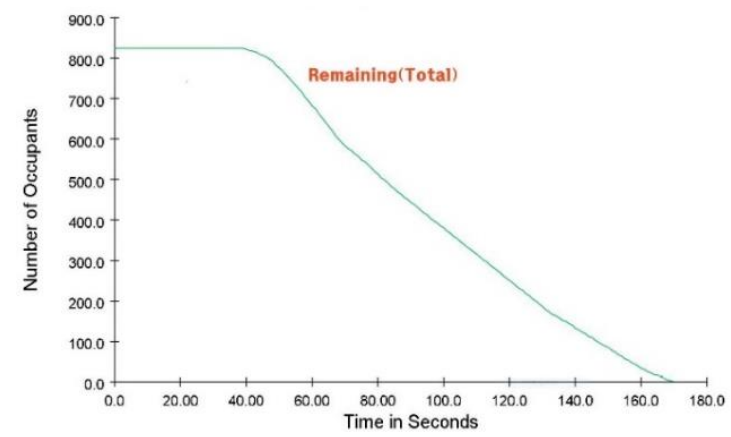

Figure 7. Changes in the number of occupants over time in Scenario 3

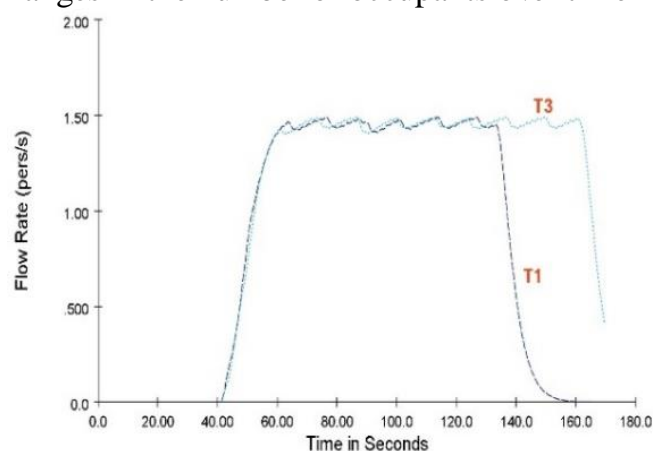

(a)

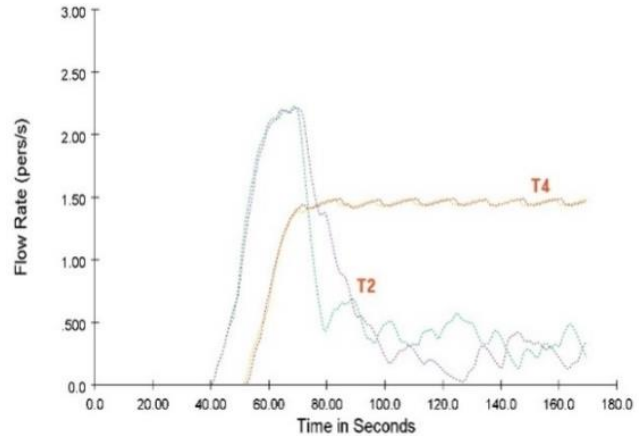

(b)

Figure 8. The Flow of Egress over Time in Scenario 3

(a) T1, T3, (b) T2, T4

3.2 Simulation results analysis

\subsubsection{Comparison of Evacuation Time by Scenario}

The initial and final evacuation time for each evacuation zone in each scenario is analyzed and the evacuation requirements are shown in Table 5. Depending on the conditions of the scenario, the evacuation request time in Scenario 1 is 203.5 seconds and the evacuation request time in Scenario 2 is 173.9 seconds, indicating that the evacuation request time is reduced when the classroom and students are distributed to the first and second floors compared to when the classroom and students are concentrated on the third floor. Scenario 3, 170.0 seconds less than the evacuation requirements in Scenario 2, was reduced by 3.9 seconds, making no significant difference. 
A Study on the Optimization of High School Buildings for Evacuation Safety: Classroom Layout and Ramps in Korea

However, Scenario 3, which is efficient in operating the school year by arranging classrooms for the same grade, is the best classroom layout.

Table 5. Major evacuation zones and evacuation times

\begin{tabular}{|c|c|c|c|c|}
\hline $\begin{array}{l}\text { Sorta } \\
\text { tion }\end{array}$ & $\begin{array}{l}\text { Evac } \\
\text { uation } \\
\text { zone }\end{array}$ & $\begin{array}{c}\text { By each } \\
\text { Evacuati } \\
\text { on } \\
\text { zone } \\
\text { Final } \\
\text { Evacuation } \\
\text { Time (s) }\end{array}$ & $\begin{array}{c}\text { Final } \\
\text { Required } \\
\text { Safe } \\
\text { Egress Time } \\
\text { by } \\
\text { Scenario } \\
\text { (s) }\end{array}$ & $\begin{array}{l}\text { J } \\
\text { udg } \\
\text { ment }\end{array}$ \\
\hline \multirow{4}{*}{$\begin{array}{l}\text { Scena } \\
\text { rio } 1\end{array}$} & $\mathrm{~T} 1$ & 146.3 & \multirow{4}{*}{203.5} & \multirow{4}{*}{$\mathrm{t}^{\mathrm{fi}}$} \\
\hline & $\mathrm{T} 2$ & 171.9 & & \\
\hline & $\mathrm{T} 3$ & 203.5 & & \\
\hline & $\mathrm{T} 4$ & 176.5 & & \\
\hline \multirow{4}{*}{$\begin{array}{l}\text { Scena } \\
\text { rio } 2\end{array}$} & $\mathrm{~T} 1$ & 145.9 & \multirow{4}{*}{173.9} & \multirow{4}{*}{$\mathrm{t}^{\mathrm{fi}}$} \\
\hline & $\mathrm{T} 2$ & 143.7 & & \\
\hline & T3 & 173.9 & & \\
\hline & $\mathrm{T} 4$ & 149.7 & & \\
\hline \multirow{4}{*}{$\begin{array}{l}\text { Scena } \\
\text { rio } 3\end{array}$} & $\mathrm{~T} 1$ & 131.8 & \multirow{4}{*}{170.0} & \multirow{4}{*}{$\mathrm{t}^{\mathrm{fi}}$} \\
\hline & $\mathrm{T} 2$ & 166.6 & & \\
\hline & $\mathrm{T} 3$ & 160.3 & & \\
\hline & $\mathrm{T} 4$ & 170.0 & & \\
\hline
\end{tabular}

3.2.2 Comparison of evacuation time between ramps and stairs

The analysis of each scenario showed that $\mathrm{T} 1$ had shorter evacuation requirements than $\mathrm{T} 3$, as shown in Table 6. The reason for T1's reduction in the evacuation requirements compared to $\mathrm{T} 3$ is that, under the conditions of Scenario 3, the difference in the escape velocity between the ramps and the stairways was changed to the ramps in order to add Scenario 4, as shown in Table 7, and compared with Scenario 3, the evacuation requirements for both slopes were compared.

Table 6. Comparison of evacuation times on ramps and stairs

\begin{tabular}{|c|c|c|c|}
\hline Sortation & $\begin{array}{l}\text { Evacuation } \\
\text { zone }\end{array}$ & Final RSET(s) & $\begin{array}{c}\text { On a T1 basis } \\
\text { Difference with T3 } \\
\text { (s) }\end{array}$ \\
\hline \multirow{2}{*}{ Scenario 1} & $\mathrm{~T} 1$ & 146.3 & \multirow{2}{*}{57.2} \\
\hline & $\mathrm{T} 3$ & 203.5 & \\
\hline \multirow{2}{*}{ Scenario 2} & $\mathrm{~T} 1$ & 145.9 & \multirow{2}{*}{28.0} \\
\hline & $\mathrm{T} 3$ & 173.9 & \\
\hline \multirow{2}{*}{ Scenario 3} & $\mathrm{~T} 1$ & 131.8 & \multirow{2}{*}{28.5} \\
\hline & $\mathrm{T} 3$ & 160.3 & \\
\hline
\end{tabular}

Table 7. Configuration of Scenario 4

\begin{tabular}{|c|c|c|c|c|c|}
\hline \multirow{2}{*}{ Condition } & \multicolumn{3}{|c|}{ Scenario conditions (classroom layout by floor(Number of classes (students)) } \\
\cline { 2 - 5 } & $\begin{array}{c}\text { Flo } \\
\text { or }\end{array}$ & $\begin{array}{c}\text { The left side of a } \\
\text { building Ramp } \\
\text { Number of classes } \\
\text { (students) }\end{array}$ & $\begin{array}{c}\text { The right side of a } \\
\text { building } \\
\text { Stairs } \rightarrow \text { Ramp } \\
\text { Number of classes }\end{array}$ & $\begin{array}{c}\text { Total } \\
\text { Number of } \\
\text { classes (students) }\end{array}$ & $\begin{array}{c}\text { en exit } \\
\text { set up }\end{array}$ \\
\hline
\end{tabular}




\begin{tabular}{|c|c|c|c|c|c|}
\hline & & & (students) & & \\
\hline \multicolumn{6}{|l|}{ Sortation } \\
\hline \multirow{4}{*}{ Scenario 4} & $1^{\mathrm{st}}$ & $5(140)$ & $5(140)$ & $10(280)$ & \multirow{4}{*}{$\begin{array}{c}\text { T1, T2, } \\
\text { T3, T4 }\end{array}$} \\
\hline & $2^{\text {nd }}$ & $5(140)$ & $5(140)$ & $10(280)$ & \\
\hline & $3^{\text {rd }}$ & $5(132)$ & $5(133)$ & $10(265)$ & \\
\hline & $\begin{array}{l}\text { tota } \\
1\end{array}$ & $15(412)$ & $15(413)$ & $30(825)$ & \\
\hline
\end{tabular}

Table 8 shows that the final passage time for evacuation zone T1 on the left side of the building in Scenario 3 is 131.8 seconds, and the final passage of evacuation time for shelter T3 is 160.3 seconds, 28.5 seconds shorter than for stairs. However, although the final passage time for T1 in Scenario 4 was 131.8 seconds, the evacuation time for T3 in Scenario 4 was 196.6 seconds, the evacuation time for T1 on the left side of the building in Scenario 3 and 4 differed by 64.8 seconds from T3 on the right side of thebuilding, increasing the evacuation time from the stairway.

Table 8. Comparison of Evacuation Time of Evacuation Exit in Scenario 3 and Scenario 4

\begin{tabular}{|r|c|c|c|}
\hline $\begin{array}{r}\text { Sce } \\
\text { nario }\end{array}$ & $\begin{array}{c}\text { Evacuatio } \\
\text { n exit }\end{array}$ & $\begin{array}{r}\text { Final } \\
\text { Evacuation } \\
\text { Time (s) }\end{array}$ & $\begin{array}{r}\text { RSET } \\
\text { Difference (s) } \\
\text { (T3 - T1) }\end{array}$ \\
\hline $\begin{array}{r}\text { Sce } \\
\text { nario 3 }\end{array}$ & $\mathrm{T} 1$ & 131.8 & \multirow{2}{*}{28.5} \\
\cline { 2 - 3 } $\begin{array}{r}\text { Sce } \\
\text { nario 4 }\end{array}$ & $\mathrm{T} 3$ & 160.3 & \multirow{2}{*}{64.8} \\
\cline { 2 - 3 } & $\mathrm{T} 1$ & 131.8 & \\
\hline
\end{tabular}

In figure 9 , the inclination angle of $34^{\circ}$ of the right staircase was reflected, and the walking speed was slower than the left ramp with the inclination angle of $15^{\circ}$, so the bottleneck phenomenon was severe and the final evacuation time was analyzed to be different.

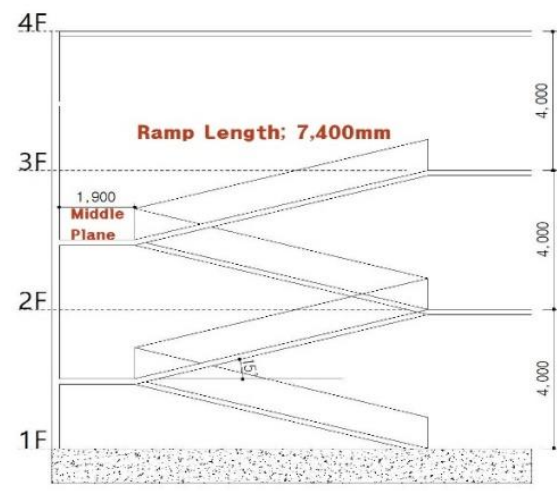

(a) 
(b)

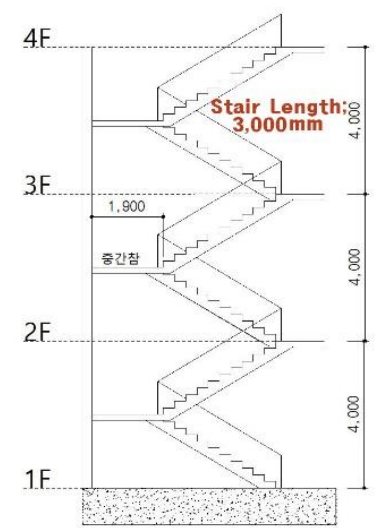

(c)

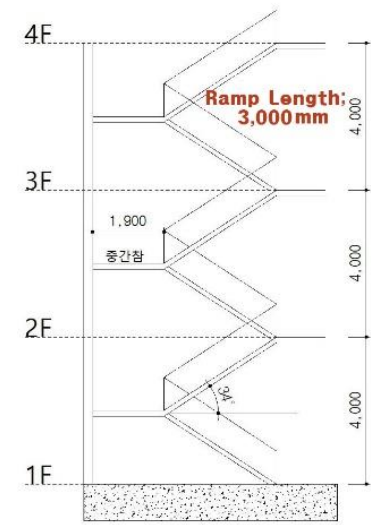

.

Figure 9. Ramp of the left side of the building and the converted Ramp on the right side

(a) Left Ramp slope- $15^{\circ}$, (b) Right stair slope- $34^{\circ}$,(c) Right side changed slope- $34^{\circ}$

\section{Conclusions}

In this study, evacuation safety and evacuation time were analyzed by setting the location of classrooms or the number of students in the evacuation training situation in high school buildings using Pathfinder evacuation simulation. Scenario-specific results are as follows:

(1) A comparative analysis of Scenarios 1 and 2 suggests that the design of classrooms downstairs is suitable for evacuation safety as a result of an analysis that reduces the evacuation requirements time in Scenario 2, which is 29.6 seconds shorter than Scenario 1, which has more classrooms and students located on the second and third floors.

(2) Evacuation time in Scenario 3, with the same number of classrooms and students on the left and right sides of the building for each grade, is 3.9 seconds shorter than Scenario 2, which focuses on the layout of classrooms downstairs, ensuring the efficiency of each school year's operation and evacuation safety.

(3) In all three scenarios, the Ramp is considered suitable for evacuation safety as a result of shorter evacuation requirements of T1 than T3. Scenario 4, which changed Scenario 3, required 36.3 seconds more of T3's evacuation time. In Scenario 4, the evacuation requirements of T3 took 64.8 seconds more than T1, indicating that the walk speed varies depending on the slope angle.

In conclusion, it was analyzed that the RSET did not exceed the evacuation possible time at all places in the building when the proper classroom arrangement centered on the shelter was made. It was also shown that the ramp with a gentle ramp than the stairs reduced the shelter demand time. Research is needed on the required safe egress time according to the slope of the ramp in the future.

\section{References}

1. National Fire Information Center, http://www.nfds.go.kr/stat/theme.do

2. S.Y. Choi et al (2016). A study on necessity of education and safety awareness to high school students when accessing laboratories, Korean Academy of Industrial-Academic Technology symposium, 17(10), 139-146.

3. J.S. Lee et al(2011), The Fire Evacuation Drills according to Sex, Age and Physical Characteristics in Junior High School and High School, Journal of the Regional Association of Architectural Institute of Korea, 13(3), 97-104.

4. W.H. Lim et al(2005), A Study on the Propriety in Evacuation Performance on Fire in School Building, Seoul National University of Technology Master's Thesis, 89.

5. S.G. Hong(2017), A study on Fire Safety Improvement through Analysis of Fire Hazards in School Facilities, Gachon University Graduate School of Industrial Environment, Master's Thesis, 131.

6. http://www.law.go.kr/ statute/ Construction Law Enforcement Decree/(20200501,30645, 20200428)/ Article 48

7. Korea Minisrty of Government Legislation, 「Performance-oriented design methods and standards for fire-fighting facilities, etc. $\lrcorner$ [Appendix 1] No.3 (Da)

8. Method of calculation on Japan Evacuation Safety Verification, Construction Ministry Notice No. 1441.

9. Korea Minisrty of Government Legislation, 「Performance-oriented design methods and standards for fire-fighting facilities, etc. $\lrcorner[$ Appendix 1] No.3 (Na), Revision December 31, (2019). 
10. Pathfinder, Thunderhead(USA), User Manual, www.thunderheadeng.com

11. Korean Statistical Information Service, Korean Body Size Survey : 120 areas of statistics (female) http://kosis.kr/statHtml/statHtml.do?orgId=115\&tblId=TX_115190171\&conn_path=I2[2] Satoh, E. at al,

"Investigation of converted walking distance considering resistance of topographical features and c hanges in physical strength by age", Journal of Architecture Planning, 133-139, (2006).

12. SFPE, "The SFPE Handbook of Fire Protection Engineering", 5th edition(2013), 2126.

13. Bello, P. O., \& Steyn, J. (2019). Students'perceptions Of The South African Police Service In Durban, South Africa: A Non-Judgmental Assessment. The International Journal of Social Sciences and Humanity Studies, 11(2), 61-85. 